\title{
Does moral evaluation mediate the relationship between cognitive moral development and reduced audit quality behavior?
}

Pupung Purnamasari

Bandung Islamic University, Indonesia

\section{Keywords}

Cognitive Moral Development, Moral Evaluation, Premature Sign-Off, Audit Quality

\begin{abstract}
The purpose of this study is to investigate whether cognitive moral development and moral evaluation factors impact an auditor's decision to engage in reduced audit quality behaviors. A total of 289 auditors participated in the survey. The Defining Issues Test (DIT) and Multidimensional Ethics Scale Revision (MES-R1) were used to measure cognitive moral development and moral evaluation. The results show that cognitive moral development and moral evaluation have a direct influence on reduced audit quality behavior. The study results also show that moral evaluation (deontology and teleology) mediates the relationship between cognitive moral development and reduced audit quality behavior. The study results have significant implications for accounting organizations and regulators concerning the effect of cognitive moral development and moral evaluation in preventing the negative impact of reduced audit quality behaviors, such as premature sign-off.
\end{abstract}

Corresponding author: Pupung Purnamasari

Email addresses for the corresponding author: purnamasariunisba@gmail.com

First submission received: $6^{\text {th }}$ April 2018

Revised submission received: $1^{\text {st }}$ July 2018

Accepted: $18^{\text {th }}$ July 2018

\section{Introduction}

Malone and Robert (1996) define reduced audit quality behaviors as the actions performed by an auditor during the audit process. Reduced audit quality behavior includes actions, such as reducing the number of audit samples, conducting a shallow review of client documents, not performing an expanded inspection when there are items that are questionable, and giving opinions before all the required audit procedures have $\mathrm{t}$ been completed (Coram, $\mathrm{Ng}$, and Woodliff, 2003). These actions may reduce the accuracy and effectiveness of the collection of audit evidence. Some previous studies have indicated that the quality of audit results are not always sufficient, even if the audit quality reduction behavior increases (Alderman and Deitrick, 1982; Svanström, 2016). One form of reduced audit quality behavior is the premature sign-off (PSO) procedure (Donnelly, Quirin, and O'Byran, 2003; Agoglia, Hatfield, and Lambert, 2015). PSO is the cessation of action required for audit procedures by not doing a complete job and ignoring other necessary audit procedures. PSO falls into the category of intentional negligence or planned cheating (constructive fraud). Such a striking omission or fraud planned over a predetermined standard represents a major infraction (Utaminingsih and Tyas, 2012). Thus, when an auditor carries out PSO, that behavior has a direct effect on the quality of the audit because when stages of the audit procedures are not implemented, the auditor's error rate in giving an opinion is high.

PSO is more unacceptable than other types of reduced audit quality behavior. PSO can also lead to an increase in lawsuits. PSO is a very significant issue because of the high risk associated with inconsistencies, which has a negative impact on the ethical responsibility associated with the accounting profession (Kaplan, 1995). The practice of PSO may lead to auditors collecting invalid or inaccurate information; thus, it can directly threaten the reliability of the financial statements that have been audited. Reduced audit quality can result in the loss of public confidence in accountants (Imhoff, 2003; Coram, Glavovic, Ng, and Woodliff, 2008) and in the profession itself. Given the importance of audit quality and 
the magnitude of the influence of PSO on that quality, prior studies on the determinants of reduced audit quality behavior are still relatively limited. This suggests the need for further investigation of the factors that facilitate and hinder this kind of behavior that are difficult to detect but which, ultimately, reduce audit quality (Svanström, 2016, p. 42).

The present study sought to answer the following question: Do individual auditor characteristics influence premature sign-off audit (PSO) behavior? The study extends the findings reported by Shaperoo, Koh, and Killough (2003) and Hunt and Vitell (2006) by integrating the characteristics of individual ethical decision-making and intention to engage in reduced audit quality behaviors, such as PSO. In the study, the individual characteristics are cognitive moral development and deontological and teleological moral evaluation. Similar to previous studies, the present study argues that the individual characteristics of an auditor have an impact on PSO behavior. The study also examines the role of deontological and teleological moral evaluation in the relationship between cognitive moral development and PSO. Deontology and teleology are two types of cognitive moral development philosophies that address different types of ethical behavior. It is supposed that these two characteristic styles of thought will exert a different level of influence on PSO behavior. Previous studies have not examined the influence of cognitive moral development on PSO using deontological and teleological moral evaluations.

This study is expected to contribute to the development of accounting and auditing literature, especially in the area concerning factors that affect PSO. Theoretically, the results of this research are expected to enrich the literature of behavioral accounting by providing empirical evidence of the impact of cognitive moral development and deontological and teleological moral evaluation on PSO audit procedures. The results of this research are useful in the advancement of study in the field of auditing, mainly the effort to improve audit quality. From a practical standpoint, accounting firms and professional organizations can use the study's findings to improve their existing audit quality by reducing the influence of factors that can lead to the occurrence of PSO behavior.

\section{Literature Review and Hypotheses Development 2.1 Cognitive Moral Development Theory}

Moral development is a change in reasoning, feelings, and behaviors regarding the standards of right and wrong. Sometimes, it has an intrapersonal dimension, which governs the activity of a person when he/she is involved in social interactions and interpersonal dimensions that regulate social interactions and conflict resolution (Rest, 1979; Ponemon, 1990; Kohlberg and Hersh, 2009). Kohlberg (1969) argues that, in principle, the process of moral development is related to justice. Moreover, moral development continues throughout a person's life. Kohlberg was later able to identify the six stages of the development of moral reasoning, which are grouped into three levels: pre-conventional, conventional, and post-conventional (Sweeney and Roberts, 1997; Kohlberg and Hersh, 2009). Lighner, Adams, and Lightner (1982) argue that the potential of an auditor engaging in PSO behavior is determined by his/her stage of moral development. According to the cognitive moral development perspective, an individual's moral capacity becomes more complex if he/she receives additional moral cognitive structure at every level of moral development growth (Ponemon, 1990).

\subsection{Premature Sign-off}

POS occurs when an auditor documents the completion of a required procedure that is not covered by other audit procedures, without performing the work or noting the omission of procedure (Shapeero, Koh, and Killough, 2003, p. 479). Although auditors are responsible for conducting a range of procedures that have been established in the professional auditing standards, in reality, they perform audit procedures upon PSO. This is done because auditors experience an "inherent cost versus quality" dilemma (McNair, 1991). Such conditions occur because auditors are required to apply high standards of quality to an audit while also being pressured to perform the audit more efficiently. The condition of the dilemma pushes an auditor to engage in PSO, which is one form of reduced audit quality behavior. Kaplan (1995) suggests that PSO behavior is a very significant issue due to the high risk 
associated with ethical responsibility in the accounting profession. Consequently, reduced audit quality behavior can result in the loss of public trust in the accounting profession.

\subsection{Cognitive Moral Development and PSO}

Previous studies have also indicated that the level of an individual's cognitive moral development has a significant relationship with PSO behavior. Ponemon (1992) suggests that higher sensitivity to ethical considerations will help an auditor critique events, problems, and conflicts. Auditors that have a high capacity to engage in ethical considerations will be better at facing conflicts and ethical dilemmas. Individuals with a high moral development will be less likely to approve of unethical behavior (Ponemon and Gabhart, 1990). Some previous studies have stated that individuals with a high level of moral development are less likely to have an unethical personality. For example, Ponemon and Gabhart (1993) note that an auditor with a higher level of ethical reasoning tends to perceive PSO behavior as negative in comparison to auditors with a lower level of ethical reasoning. Based on the results reported in the literature, it is expected that the level of cognitive moral development has a negative relationship with PSO behavior.

H1: There is a negative relationship between cognitive moral development and premature sign-off.

\subsection{Deontological Moral Evaluation and PSO}

Hunt and Vitell (1986) argue that ethical assessment is the result of a combination of deontological and teleological moral evaluations. Deontology theory is based on a moral imperative of what is right and wrong. A deontological moral evaluation highlights the inherent morality that underlies behaviors (Shapeero et al., 2003). Previous studies have indicated that deontological moral evaluation may have a significant effect on an ethics-based decision-making process conducted by an accountant. For example, Ponemon and Gabhart (1993) suggest that individuals with a high degree of integrity and capacity for ethical assessment tend to be free of bias from internal and external pressures . Therefore, in accordance with the view that respondents who consider PSO behavior to be an ethical issue, it is expected that the use of deontological moral evaluation will have a negative relationship with the intention to conduct PSO (Shapeero et al., 2003).

$\mathrm{H} 2$ : There is a negative relationship between deontological moral evaluation and premature sign-off.

\subsection{Teleological Moral Evaluation and PSO}

Hunt and Vitell (1986) suggest that the teleology theory approach is frequently used to distinguish right from wrong or good from bad, based on the results or consequence of a decision or action. Therefore, teleological evaluation is associated with the consequences brought about by engaging in a specific behavior. However, previous studies have shown that it is difficult for individuals to apply this theoretical approach in decision making. In accordance with the view that respondents who consider PSO to be an ethical issue, it is expected that the use of teleological moral evaluation will have a positive relationship with PSO. A previous study has also shown that individuals who engage in PSO have expectations that their actions will result in specific benefits or advantages. Therefore, it is expected that the use of teleological moral evaluation has a positive relationship with the intention to engage in PSO (Shapeero et al., 2003).

H3: There is a positive relationship between teleological moral evaluation and premature sign-off.

\section{Research Methods 3.1 Sample}

Table 1 presents information on the accounting firms contacted and the total number of respondents that participated in the survey. As seen in Table 1, 660 questionnaires were sent to the respondents. Of those, 289 questionnaires were returned. The response rate was $43.78 \%$. 
Table. 1 Questionnaire Distribution

\begin{tabular}{|l|l|l|l|}
\hline No & Accounting Firm & Sent & Returned \\
\hline 1 & Purwantono, Sarwoko \& Sanjaya, affiliated with Ernst \& Young Global & 165 & 97 \\
\hline 2 & Haryanto Sahari, affiliated with Price Waterhouse Cooper & 165 & 69 \\
\hline 3 & Osman Bring Satrio, affiliated with Deloitte Touche Tohmatsu & 165 & 51 \\
\hline 4 & Sidharta Sidharta \& Widjaya, affiliated with KPMG International & 165 & 72 \\
\hline & Total & 660 & 289 \\
\hline & Response rate: $(289 / 660) \times 100 \%$ & & $43.78 \%$ \\
\hline
\end{tabular}

\subsection{Measurement of the Variables and Data Analysis}

The PSO variable was measured by the instruments developed from the indicators from the Indonesian Public Accountants Professional Standards. The PSO instrument consists of 10 questions. The questionnaire responses were rated using a 7-point scale, ranging from 1 (strongly disagree) to 7 (strongly agree). A high score indicates that a respondent accepts the PSO behavior of audit procedures. In contrast, a low score shows that a respondent does not accept (reject) the PSO behavior of audit procedures. Table 2 presents the PSO indicators. Cognitive moral development was measured by the Defining Issue Tests (DIT) (Rest, 1979). The Multidimension Ethics Scale Revision (MES-R1) was used to measure the deontological moral evaluation and teleological moral evaluation constructs (Cohen, Pant, and Sharp, 1983). Structural equation modeling (SEM) with the Analysis Moment of Structure (AMOS) program was used to analyze the data.

Table 2. PSO Indicators

\begin{tabular}{|l|l|}
\hline Code & PSO Indicators \\
\hline PSO1 & Requires understanding of business and industrial clients in planning an audit \\
\hline PSO2 & Uses consideration of internal control system in financial statements audit \\
\hline PSO3 & $\begin{array}{l}\text { Uses management assertion information in formulating audit objectives and designing the } \\
\text { subtantive tests }\end{array}$ \\
\hline PSO4 & Uses internal auditor function in an audit \\
\hline PSO5 & Performs analytic procedures in audit planning and reviewing \\
\hline PSO6 & Performs confirmations with third parties in financial statements audit \\
\hline PSO7 & Uses management representation in financial statements audit \\
\hline PSO8 & Performs compliance tests on application of computer online system control \\
\hline PSO9 & Reduces the number of samples determined in the financial statements audit \\
\hline
\end{tabular}

Note: Adopted from Standard Professional Akuntan Publik Indonesia (SPAP)/Indonesian Public Accountants Professional Standards.

\section{Findings and Discussion}

Table 3 provides the descriptive statistics of the variables. As shown, the mean of PSO is 28.57 and the mean of teleological moral evaluation is 47.51 . These means are lower than the scale midpoint $(40 ; 64)$. The mean of cognitive moral development (40.88) and deontological moral evaluation (19.60) are slightly above the scale midpoint $(36 ; 20)$. 
Table 3. Descriptive Statistics Variables

\begin{tabular}{|l|l|l|l|l|}
\hline Variables & $\begin{array}{l}\text { Theoretical } \\
\text { Range }\end{array}$ & $\begin{array}{l}\text { Actual } \\
\text { Range }\end{array}$ & $\begin{array}{l}\text { Actual } \\
\text { Mean }\end{array}$ & St.Dev \\
\hline Premature Sign-Off (PSO) & $10-70$ & $11-59$ & 28.57 & 10.48 \\
\hline Cognitive Moral Developmment (CMD) & $12-60$ & $24-59$ & 40.88 & 8.31 \\
\hline Deontological Moral Evaluation (DME) & $5-35$ & $6-33$ & 19.60 & 6.05 \\
\hline Teleological Moral Evaluation (TME) & $16-112$ & $19-104$ & 47.51 & 17.12 \\
\hline
\end{tabular}

Table 4 presents a summary of the construct reliability (CR) and variance extracted (VE). As shown, each indicator has a CR value higher than 0.65 . Thus, it can be concluded that all the indicators can be used to measure the latent variables: cognitive moral development, deontological moral evaluation, and teleological moral evaluation.

Table 4. Construct Measurement

\begin{tabular}{|l|l|l|}
\hline Variables & Construct Reliability (CR) & Variance Extracted (VE) \\
\hline Cognitive moral development (CMD) & .956 & .645 \\
\hline Deontological moral evaluation (DME) & .863 & .557 \\
\hline Teleological moral evaluation (TME) & .957 & .583 \\
\hline Premature sign off (PSO) & .931 & .602 \\
\hline
\end{tabular}

Table 5 presents the SEM results. Based on the information presented in Table 4, it can be seen that, overall, the model is acceptable. The chi-square value is 2538.719 with a p-value $<0.001$ (less than 0.05 ) and the goodness of fit index (GFI) value for the model is 0.739 (less than 0.90 ). While this shows that the model is not fit yet, based on the root mean square error of approximation (RMSEA) value $(0.047<$ $0.08)$, TLI value $(0.911>0.90)$, and comparative fit index $(\mathrm{CFI})$ value $(0.915>0.90)$, it can be concluded that, overall, the model is still acceptable.

Table 5. Structural Equation Modelling Results

\begin{tabular}{|c|c|c|c|}
\hline Relationship & Standardized regression weight & p-value & R-square \\
\hline $\mathrm{CMD} \rightarrow \mathrm{PSO}$ & -.130 & .078 & \multirow{3}{*}{.65} \\
\hline $\mathrm{DME} \rightarrow \mathrm{PSO}$ & -.205 & .009 & \\
\hline $\mathrm{TME} \rightarrow \mathrm{PSO}$ & .280 & .000 & \\
\hline
\end{tabular}

The first hypothesis stated that there is a negative relationship between cognitive moral development and PSO. Based on the SEM results, as presented in Table 5, it can be seen that the standardized regression weight of the effect of cognitive moral development on PSO is -0.130 ( $p$-value 0.078). This finding suggests that cognitive moral development has a negative effect on PSO. This means that individuals with a high level of moral development will have a high tendency not to do engage in reduced audit quality behaviors, such as PSO. This finding is consistent with Trevino and Youngblood (1990), who stated that individuals with high moral development tend to be more sensitive to ethical 
problems and situations. Individuals who have high cognitive moral development adhere to the principles of universal justice and they respect other people. These individuals will be equitable when addressing the interests of others because they can be expected to look at dubious behavior as being less acceptable, and they are less inclined to commit unethical acts in comparison to individuals with a lower level of moral development. The results of this research are supported by Wilopo (2006), who stated that moral development has a negative influence on dysfunctional behavior. However, the present study's findings do not support the results in Shapeero et al.'s (2003) study, which was unable to prove that cognitive moral development had an influence on PSO behavior.

The second hypothesis stated that deontological moral evaluation has a negative effect on PSO. Based on the SEM results presented in Table 5, the coefficient path of deontological moral evaluation on PSO is -0.205 , and the probability is less than 0.05 . The result suggests that the better the auditors' ability to apply a deontological moral evaluation, the lower the probability that they will engage in PSO audit procedures. Individuals that use deontological evaluation have high level of integrity and engage in ethical assessment, and they tend to be free of bias and pressure both inside and outside the public accounting profession (Ponemon and Gabhart, 1993). This finding is not consistent with Shaperoo et.al (2003). This finding supported the cognitive moral development theory; an auditor with the level of moral development has intentions to maintain the rules and authority to be independent when the his/her behaviour is coherent with the norms of his/her group (Sweeney and Robert, 1997).

The third hypothesis stated that teleological moral evaluation has a positive effect on PSO. The coefficient path of teleological moral evaluation on PSO is 0.280 (Table 5). Based on the result, it can be concluded that the lower the auditors' ability to apply a teleological moral evaluation, the lower their intention to engage in PSO. This means that individuals who use teleological moral evaluation when making decisions will have a high tendency to engage in PSO. Moreover, it can be said that individuals who engage in PSO have expectations that their actions will provide specific benefits or advantages (Shapeero et al., 2003). The finding of this study is not consistent with Shaperoo et.al (2003). Their finding showed that teleological moral evaluation does not have effect on PSO. Therefore, this study contributes to literature by showing the positive relationship between teleological moral evaluation and PSO.

\subsection{Indirect Effect Tests}

Table 6 presents the results of the indirect effect tests. As seen, the influence of cognitive moral development on PSO mediated by deontological moral evaluation is $13.5 \%$, with a negative direction and a p-value of 0.06. A similar result was also found for the effect of cognitive moral development on PSO mediated by teleological moral evaluation: $13.6 \%$ and a $p$-value of 0.00 .

Table 6. Indirect Effect Tests

\begin{tabular}{|l|l|l|l|}
\hline Mediation effect & Mediating variable & Indirect effect & p-value \\
\hline $\mathrm{CMD} \rightarrow \mathrm{PSO}$ & DME & $.657 \times-.205=-.135$ & .006 \\
\hline $\mathrm{CMD} \rightarrow \mathrm{PSO}$ & TME & $.486 \times .280=-.136$ & .000 \\
\hline
\end{tabular}

\subsection{Conclusions, Implications, Limitations, and Direction for Further Research}

The study investigated the influence of cognitive moral development, deontological moral evaluation, and teleological moral evaluation on PSO behavior. The results demonstrate that cognitive moral development and deontological moral evaluation have a significant negative effect on PSO behavior. Furthermore, the results show that teleological moral evaluation has a positive effect on an auditor's decision to engage in PSO audit procedure behavior. The study's findings suggest that ethical decision making in the field of accounting, especially decisions made by an auditor engaging in PSO behavior, is influenced by an individual's level of moral development. The results of this study have some theoretical and practical implications. First, the results provide evidence that the individual characteristics of auditors, such as cognitive moral development, deontological moral evaluation, and teleological moral 
evaluation, affect their PSO behavior, either directly or indirectly. This finding indicates that accounting firms need to consider the importance of the level of an auditor's moral development. Accounting firms and public accounting professionals need to consider undergoing personality training and engaging in ethical socialization practices before implementing audit procedures. It is expected that these efforts may increase the awareness of auditors, enabling them to avoid engaging in unethical behaviors, such as PSO.

Second, although the results demonstrate that the intention of auditors to engage in PSO behavior is low, it is important for accounting firms to maintain audit quality by increasing their supervision over auditors when they are performing audit procedures. These actions are expected to enable firms to avoid reduced audit quality. Third, for governments and professional accounting organizations, this finding can offer data that can be used to develop practical policies to build a framework for applying strict sanctions on auditors that engage in unethical behavior when performing audits. Fourth, the results are also useful for academics who might be considering adding the subject of ethics to their accounting curriculum to increase their students' understanding of professional ethics.

The limitation of this study is that it only focused on the Big Four auditing firms; thus, generalization of its findings is limited. As the nature of study in ethics area is sensitive, it is possible that the answers of respondents do not represent the real condition. Future research should overcome the limitations of this study by considering respondents from non-Big Four accounting firms. Also, future study may employ the experiment method to control the effect of each independent variables on PSO.

\section{References}

Agoglia, C.P., Hatfield, R.C. and Lambert, T.A. (2015) 'Audit team time reporting: An agency theory perspective', Accounting, Organizations and Society, Vol. 44, pp. 1-14.

Alderman, C.W. and Deitrick, J.D. (1982) 'Auditor's Perception of Time Budget Pressures and Premature Sign Offs: A Replication and Extension', Auditing: A journal of Practice and Theory, Vol. 1 No. 4, pp. 54-68.

Cohen, J.R., Pant, L.W. and Sharp, D. (1983) 'A validation and extension of a multidimensional ethics scale', Journal of Business Ethics, Vol. 12 No. 1, pp. 13-26.

Coram, P., Glavovic, A., Ng, J. and Woodliff, D.R. (2008) 'The moral intensity of reduced audit quality acts', Auditing: A Journal of Practice and Theory, Vol. 27 No. 1, pp. 127-149.

Coram, P., Ng, J. and Woodliff, D. (2003) 'A Survey of Time Budget Pressure and Reduced Audit Quality Among Australia Auditors', Australia Accounting Review, Vol. 13 No. 1, pp. 38-44.

Donnelly, D.P., Quirin, J.J. and O'Byran, D. (2003) 'Auditor acceptance of dysfunctional audit behavior: An explanatory model using auditors' personal characteristics', Behavioral Research in Accounting, Vol. 15, pp. 87110.

Hunt, S.D. and Vitell, S. (1986) 'A general theory of marketing ethics. ', Journal of Macromarketing, Vol. 6 No. Spring, pp. 5-16.

Imhoff, J.E.A. (2003) ‘Accounting Quality, Auditing and Corporate Governance', Accounting Horizon, Vol. 17, pp. 117128.

Kaplan, S.E. (1995) 'An Examination of Auditors' Reporting Intentions Upon Discovery of Procedures Prematurely Signed-Off Auditing: A Journal of Practice and Theory', Auditing: A Journal of Practice and Theory, Vol. 14 No. 2, pp. 90-104.

Kohlberg, L. (1969), 'Stage and sequence: the cognitive developmental approach to socialization. In Goslin, D.A Handbook of Socialization Theory and Research', Rand McNally, Chicago.

Kohlberg, L. and Hersh, R.H. (2009) 'Moral development: A review of the theory', Theory Into Practice, Vol. 16 No. 2, pp. 53-59.

Lighner, S.M., Adams, S.J. and Lightner, K. (1982) 'The influence of situational, ethical, and expectancy theory variables on accountans's underreporting behavior', Auditing: A Journal of Practice and Theory, Vol. 2 No. 1, pp. $1-12$.

Malone, C.F. and Robert, R.W. (1996) 'Factors Associated with Incidence of Reduced Audit Quality Behaviors', Auditing: A Journal of Practice and Theory, Vol. 15 No. 2, pp. 49-64.

McNair, C.J. (1991) 'Proper compromises: The management control dilemma in public accounting and its impact on auditor behavior', Accounting, Organizations and Society, Vol. 16 No. 7, pp. 635-653.

Ponemon, L.A. (1990) 'Ethical judgments in accounting: A cognitive-development perspective', Critical Perspectives on Accounting, Vol. 1, pp. 191-215. 
Ponemon, L.A. (1992) 'Ethical reasoning and selection-socialization in accounting', Accounting, Organizations and Society, Vol. 17 No. 3/4, pp. 239-258.

Ponemon, L.A. and Gabhart, D.R.L. (1990) 'Auditor independence judgements: A cognitive-developmental model and experimental evidence', Contemporary Accounting Research, Vol. 7 No. 1, pp. 227-251.

Ponemon, L.A. and Gabhart, D.R.L. (1993), 'Ethical reasoning in accounting and auditing, CGA-Canada Research Foundation.', Canada Research Foundation.

Rest, J.R. (1979), 'Development injudging Moral Issues ', University of Minnesota Press., Minneapolis, MN.

Shapeero, M., Koh, H.C. and Killough, L.N. (2003) 'Underreporting and premature sign-off in public accounting', Managerial Auditing Journal, Vol. 18 No. 6/7, pp. 478-489.

Svanström, T. (2016) 'Time Pressure, Training Activities and Dysfunctional Auditor Behaviour: Evidence from Small Audit Firms', International Journal of Auditing, Vol. 20 No. 1, pp. 42-51.

Sweeney, J.T. and Roberts, R.W. (1997) 'Cognitive moral development and auditor independence', Accounting, Organizations and Society, Vol. 22 No. 3/4, pp. 337-352.

Trevino, L.K. and Youngblood, S.A. (1990) 'Bad apples in bad barrels: A causal analysis of ethical decision making behavior', Journal of Applied Psychology, Vol. 75 No. 4, pp. 378-385.

Utaminingsih, U. and Tyas, T. (2012), 'Analysis factors influencing premature sign-off of audit procedure in audit firms in Central Java, in Conference in Business, Accounting and Management.

Wilopo, R. (2006) 'Factors affecting the dysfunctional of auditor behaviour:: Study in audit firms in East Java', Jurnal Akuntansi dan Teknologi Informasi, Vol. 5 No. 2, pp. 1-12. 